\title{
A Study of China's Ancient Supervision System and Its Reference
}

\author{
Deshu Xue ${ }^{1, \mathrm{a}}$ Ping Zhou ${ }^{2, \mathrm{~b}}$ \\ ${ }^{1}$ Faculty of Law, Shengli College China University of Petroleum, Dongying District, Dongying, Shandong, China \\ ${ }^{2}$ Faculty of Law, Shengli College China University of Petroleum, Dongying District, Dongying, Shandong, China \\ aEmail: slxyxds@163.com \\ ${ }^{b}$ Email: 1191957291@qq.com
}

\begin{abstract}
The ancient Chinese supervision system has a long history. As an important part of traditional Chinese political practice, it is a state supervision system established to maintain the established ruling order, restrain power, supervise government officials, punish corruption, maintain the integrity of officials, and ensure the normal operation of the state machinery. By analyzing the construction of the ancient Chinese supervision system, we can explore its legal experience based on our national conditions, grasp its development rules, take the essence and discard the dregs, which is of reference significance for the contemporary promotion of anti-corruption work and strengthening the construction of clean government.
\end{abstract}

Keywords: Ancient supervision system, power constraint, reference study

\section{OVERVIEW OF THE ANCIENT CHINESE SUPERVISION SYSTEM}

\subsection{The history of ancient Chinese supervision system}

\subsubsection{Budding period}

Supervisory activities existed during the Xia, Shang, and Zhou Dynasties, but there was no relatively specific supervision system. During the Spring and Autumn Period and the Warring States Period, the power of supervision was given to the imperial officials who were in charge of historical documents. According to Records of the Grand Historian: Huaji Humorists, officials did not dare to indulge in drinking because of "enforcers on the side, clerks in the back", which shows that the imperial officials had a certain deterrent effect in executing their supervisory power over all officials. However, in general, the supervision system was still in its infancy; no special supervision regulations had been formulated, nor was a special supervision agency set up.

\subsubsection{Formation period}

During the Qin Dynasty, as the starting point of feudal monarchical despotism, after the Reforms of Shang Yang and the annexation wars, the strengthening of the central and local government and officials at all levels was used by the Qin Dynasty as a measure to achieve the purpose of consolidating imperial power, compared with the supervision system in its embryonic stage, where the ruler held the state power and decided everything arbitrarily and strongly, which was an extremely obvious feature of the supervision system of the Qin Dynasty. After the unification of Qin, an office of imperial historian was set up in the central government, whose main duty was to correct the officials and assist the prime minister in the righteousness of justice. At the same time, a remonstrance system was set up. A remonstrant could exercise the right of suggestion and deliberation. Since the Qin Dynasty unified China, the difficulty of management had increased. Therefore, an office of imperial governor was set up at the local level to consolidate the unification to a certain extent, and an office of county imperial governor was set up aiming to supervise the local officials and keep sending talents to the higher level. The setting up of the offices of imperial governor and county imperial historian directly reflects that the supervision system was initially established in ancient China, but no special monitoring agency had been set up yet. 
The Han dynasty inherited the Qin system and further developed it by setting up the censorate in the central government to exercise monitoring duties, which was also the first specialized monitoring agency in Chinese history, with the imperial governor performing monitoring duties and the prime minister temporarily dispatching imperial officials at the local level. This system of supervision was more stringent than that of the Qin Dynasty.

\subsubsection{Mature period}

During the period of the Wei, Jin and Southern and Northern Dynasties, when there was turmoil brought by war, frequent changes of dynasties, and an emergence of ethnic integration, the supervision system did not fully develop. In order to adapt to the centralization of power, the censorate was changed into a supervisory organ directly under the emperor as the highest supervisory organ, forming a pattern in which the censorate was the main body, and its authority to supervise officials was strengthened. In terms of the number and division of labor of the censorate, the structure of this period was reasonable and functioned well.

The Tang Dynasty was the heyday of Chinese civilization. In the early Tang dynasty, the central censorate was a specialized organ for supervising court officials, and was divided into "three courts", each covering a different scope of responsibility. At the local level, the censorate still inspected the localities from time to time, while at the same time, the inspection officials changed from dispatching to permanent inspection officials, and interviewers were in charge of inspection at the local level, which was a highly independent local inspection system.

\subsubsection{Intensive completion period}

During the Song dynasty, the strengthening of feudal absolutism, economic prosperity and the conflicts between centralized power and decentralized power, led to the emergence of the Song supervision system, which was also an important period of strengthening and improving the supervision system in ancient China. At the central level, the censorate inherited the "three courts" of the Sui and Tang dynasties; however the functions of the censorate were gradually merged into the temple court and the court of censors. The system was established with a fixed staff, and the scope of supervision and impeachment of the imperial officials was broad and detailed. In the censorate, there were also six other imperial officials, which expanded the functions of the imperial officials, i.e., to correct the officials and to suggest the emperor in the imperial government.

The Yuan Dynasty inherited the Song Dynasty. At the central level, the censorate did not set up a court, but kept a court of inspection. At the local level, the office of special imperial censor was abolished. The unity of imperial censors and the court was created in this period to strengthen the supervision of local officials, and the censorate was set up in all provinces of the Yuan dynasty, which was the work agency of the central imperial censorate sent to the local level. Besides, 22 inspection districts were also divided, each of which was set up with the Department of Political and Integrity, building a comprehensive system of supervision.

During the Ming and Qing dynasties, as feudal rule had reached its peak, the supervision system was reformed accordingly to meet the development of the times. During the Ming Dynasty, the inspectorates and the six ministerial departments supervised each other in the central government. At the local level, the authority of supervision was exercised by the Criminal Investigation Department, the governors, and the imperial historians by going out on inspection tours. During this period, the "Constitution" and other related supervision regulations were formulated. The Qing dynasty compiled the "The Emperor Designated Censorate Regulations" and followed the system of the Ming dynasty. The court of censors continued to be established, and the ancient system of supervision also took on rigor and unity.

\subsection{Characteristics of the ancient Chinese supervision system}

\subsubsection{Single line vertical}

To ensure the implementation of the supervisory power, the supervisory institutions gradually became independent, and the supervisory officials were directly subject to the central government. The single-line vertical character of the supervision system has been initially revealed since the establishment of the supervision system in the Qin Dynasty. The censorate in the central government was established as the central supervisory organ, where the grand censor was assigned as the governor of the censorate with the subordinates of imperial chancellor, the imperial minister and the imperial historian. At the local level, the supervising county imperial historians were responsible for the local supervisory. In the Han dynasty, the supervisory organs were gradually separated from the administrative organs, and the censorate became an independent supervisory organ, with the establishment of the office of local inspector. In the local level, the thirteen provincial governors replaced the former imperial officials of the county to exercise the supervisory authority. During the Wei, Jin, and Southern and Northern Dynasties, the local inspectors and the provincial governors were changed to belong to local supervisory organs, and the supervisory duties were executed at the central level by the censorate and the imperial censors, which became independent supervisory organs. 


\subsubsection{Emphasis on the supervision of inspectors}

The mutual supervision of the imperial officials and the supervising imperial officials within the court of censors shows that in addition to supervising the officials, the ancient supervising officials also formed an internal supervision system within the the system to prevent the officials from using their power for personal gain. The assessment of supervisors was strengthened, and the results of the assessment were used as an important basis for the promotion and transfer of supervisors. Tang Code - Law on Litigation provided that: "If the supervisors know that their ministries have violated the law but do not impeach them, the offender's crime shall be reduced by three degrees. The correcting official shall be reduced by the two degrees." In ancient times, there were various ways of supervision, one of which was the Law of Refutation. If a document was found to be unreasonable, it would be ordered to be corrected within a certain period of time; the second was the inspection method, which was mainly for the supervision of localities; the third was the law of secret service detection. Mainly, officers were dispatched to carry out secret service activities to hide their identities from officials and people to search for information [1].

\subsubsection{Strict selection of inspection officials}

The purpose of supervision was to prevent corruption. Consequently, the selection and appointment criteria for supervising officials were particularly strict. In the Tang Dynasty, it was stipulated that "all officials, who do not go through the states and counties, can not enter the censorate." In the Song Dynasty, Emperor Ren Zong required inspectors to be "two-term judges", while Emperor Xiao Zong required them to have experience in grassroots work, so that officials were familiar with public sentiment and the situation in the officialdom, which provided favorable conditions for carrying out tasks after taking office. Ming Chengzu Zhu Di once said that the imperial censor, as a close friend of the emperor, needed to have relevant academic knowledge. In the Sui and Tang dynasties, most of the officials who served as inspectors were selected through the imperial examinations. In ancient times, the principle of avoidance was also attached to the selection of inspectors. For example, they could not serve as inspectors in their original domicile or in the region where they used to serve, and those recommended by the prime minister and their relatives, children, and subordinates were not allowed to serve as inspectors [2], which aims to ensure fairness and impartiality of the inspection activities.

\section{THE LIMITATIONS AND ROLE OF THE ANCIENT CHINESE SUPERVISION SYSTEM}

\subsection{The limitations of the ancient Chinese supervision system}

The ancient system of supervision in China has been in place for more than 2,000 years, and has indeed played a positive role in disciplining bureaucrats, preventing official corruption and maintaining feudal rule.

\subsubsection{The power operation mechanism of "Rule by man"}

The emperor was the supreme power owner, whose power was not subject to any form of constraint, and the law created tension with power. The supervision system derives its power from the imperial power and serves as the eyes and ears of the emperor, a tool for maintaining feudal rule, making it independent of the bureaucracy but not of the imperial power; the supervision system tends to be constrained in its role by the imperial power. Whether the supervision system could ideally fulfill its role depended largely on the will of the emperor. The effective operation of the supervision system is often guaranteed without the support of laws, but supervision laws and regulations are mainly promulgated by the emperor. If the emperor is incompetent, it will seriously affect the effectiveness of supervision and gradually move away from the ideal of judicial justice and punishment of corruption; if the emperor is wise, he will sometimes make corresponding laws and regulations to restrain himself [3].

\subsubsection{Expanded powers of inspection officials}

The power of the supervisory officials was subject to imperial power, and the emperor kept increasing the power of the supervisory officials, which on the one hand did help to safeguard their functions, but at the same time made the supervisory officials attempt to interfere with other work in the administrative field that they should not have interfered with, making the normal exercise of the powers of other departments impossible, ganging up on private parties, colluding with local officials and other corrupt phenomena. If this phenomenon kept spreading within the supervision system, there would be "deceiving the top and concealing the bottom", local protectionism and other phenomena. The emperor's lack of concern for the dynastic administration, coupled with the abuse of power by the supervisory officials, led to political disorder, paralysis of power, dynastic changes, and the loss of the supervisory function itself, which defeated the original purpose of establishing the supervision system [4]. 


\subsubsection{Low status of inspection officials}

The emperor gave greater power to the supervisory officials. To prevent them from threatening the emperor's rule and forming a strong political power, the rank of the supervisory officials was low; however, in the process of executing the supervisory power, it was inevitable that they would impeach the power and would suffer unreasonable retaliation. The disadvantages of the "inferiority to superiority" were exposed, and it was necessary to raise the rank of the supervisory officials to a certain extent to better regulate the officials [5].

\subsection{The role of ancient Chinese supervision system}

The supervision system has played a positive role in the clean government in ancient China by centralizing the allocation of power, bringing together the forces of anticorruption, and enhancing the efficiency of the all-round supervision system.

\subsubsection{Weakening corruption}

In ancient China, officials had the right to impeach any official who committed corruption, malfeasance, gang affiliation, and other disciplinary actions. In order to prevent corruption, the Qin Dynasty established the offices of imperial governor and supervising imperial official; the Han Dynasty established the office of prefectural governor; the Ming Dynasty established the offices of the left and right imperial officials, deputy imperial officials, commander-in-chief imperial officials, the Ke Dao officers, etc. Regardless of their ranks, they could fully play their supervisory functions and impeach and petition officials, thus enabling them to improve the quality and efficiency of their work and achieve the purpose of maintaining feudal rule.

\subsubsection{Effective supervision of justice}

In the Han Dynasty, the supervision of justice was an important duty of the prefectural governors, which included investigating cases in the counties under their jurisdiction. Each county was required to keep a list of the status of criminals for the prefectural governors' review. In response to any wrongful imprisonment found, the prefectural governors would order the magistrates to make timely corrections. At the same time, the governors also supervised whether the facts in the verdict were clearly investigated, whether the evidence was solid and sufficient, whether the procedure was proper, and whether the nature was accurate. In the Yuan Dynasty, it was stipulated that criminals for various crimes were to be interrogated equally by officials, not by special committees or officials. If the rules of supervisory correction were violated, supervisory officials could object to the treatment and verdict such as picketing illegal detention and torture.

\section{A CONTEMPORARY STUDY OF THE ANCIENT CHINESE SUPERVISION SYSTEM AND ITS ANALYSIS}

\subsection{The main problems of the contemporary supervision system}

With the in-depth development of the contemporary supervision system, based on practice, there will always be new problems, challenges and situations. Therefore, we need to think rationally about the existing problems, and improve them.

\subsubsection{For special inspectors}

From the existing provisions, the special inspection is not only the duty of external supervision and the staff of the supervisory organs, but also the work of making suggestions on various legal documents and other norms formulated by the discipline inspection and supervision, conducting investigation and research at the grassroots level, etc. The special inspector does not perform his duties in a full-time manner. These factors bring the special inspector the fact that " the spirit is willing but the flesh is weak ", distracting them from supervision. When performing their duties, special inspectors may be in danger and need relief. These are not detailed in the Supervision Law for special inspectors, making them lack legal support in the process of exercising their authority [6].

\subsubsection{For the interface between law and law}

The Supervision Law only contains provisions on the investigation of evidence of crimes in office by the supervisory organs. The relevant provisions on prosecution and trial are applicable to the Criminal Procedure Law, but when it comes to the legality of the evidence related to crimes in office, the contradiction is manifested. Although the Supervision Law has stated that the evidentiary materials collected by the supervisory organs in the investigation must be connected and consistent when used in criminal proceedings [7], in practice, it undoubtedly poses a problem for the judiciary, so there is a need to establish consistent norms in terms of evidentiary standards. In practice, when faced with compensation cases concerning the supervisory authorities, what standards should be applied, and this legal gap needs to be closed in time [8].

\subsubsection{For retention}

As a means of restricting personal freedom, it is rigid. But in the Supervision Law lien measures exist as a means of obtaining evidence. The relevant provisions in 
the law so that the lien measures and other conventional means of investigation have the same properties, did not provide for the relevant concepts into coercive measures. Compared to the previous, they are more standardized, providing for the application of the subject for all monitoring objects. According to the provisions of the Supervision Law, in practice, it is applicable to all problematic supervisory subjects, thus leading to abuse, so that this measure is not formulated with sufficient rigor, and may be inappropriately handled. In addition, the adoption of lien measures will inevitably have a negative impact on the subject, and the Supervision Law does not provide detailed provisions on the way of relief for the subject, how to effectively supervise the entire process of lien, and the duration of lien [9].

\subsection{Inspiration of the ancient supervision system to the contemporary supervision system}

Since the 18th Party Congress, China's anticorruption work has significantly progressed, with a highly unified, authoritative and efficient national supervision system that consistently adheres to the important directive of "no restricted area, full coverage and zero tolerance" to guide the construction of clean government. Although the ancient system of supervision aimed to maintain the feudal monarchy, the effective experience accumulated during its implementation still has a certain reference value for the continuous improvement of the contemporary supervision system in China.

\subsubsection{Ensuring the people's attributes of the supervision system}

The contemporary Chinese supervision system is constructed with the purpose of safeguarding the interests of the people. Compared with ancient times, in the contemporary fight against corruption, the power of the people should be given full play to always supervise the party members and cadres, forming a set of bottom-up supervision mechanism. As Mao Zedong once said, let the people supervise the government so that the government will not dare to slacken off. In the process of formulating laws and regulations about supervision, the people should be widely consulted, so that they can actively participate in punishing corruption. Meanwhile, the will of the Party and the demands of the people can be raised to law through the formulation of the Supervision Law to ensure the realization of the interests of the people [10].

\subsubsection{Implementing multiple supervision}

As the most important system to eliminate corruption, in order to fully play its role, its internal supervision is also essential. Drawing on the ancient measures to strengthen internal supervision of the supervision system, contemporary supervisory organs establish a supervisory body, strengthen the style of construction of the supervisory personnel, and strive to build the supervisory team into a loyal, clean and responsible team and to establish a good image, which is critical to enhance the authority of the supervision authority. At the same time, internal supervision alone can not achieve the best results. Therefore, a good supervision system also needs to be complemented by various external supervision, such as the supervision of the people, the supervision of information network, the supervision of mass media, the supervision of public opinion, the strengthening of information disclosure, etc., so that the supervision system can develop in the long run [11].

\subsubsection{Independence of the supervisory authority}

Throughout the ancient system of supervision, in order to better play the role of supervision, the supervisory agencies and administrative agencies are separated from each other, forming an independent and vertical one-way management model. In contemporary times, the supervisory organs are no longer subject to the emperor only as in ancient times. The supervisory organs are co-located with the Discipline Inspection Commission and are under the leadership of the higher supervisory organs and the people's government at the same level. At the same time, the government had to reasonably interfere with the supervision work, each in its own way, to clarify the functional boundaries, to ensure the independence of the supervisory organs, to ensure effective supervision of officials, to enforce the law impartially, and to realize the absolute authority of the supervisory organs [12].

\section{CONCLUSION}

The establishment of the ancient supervision system played a positive role in promoting the effective implementation of various state tasks and rectifying the style of corrupt officials. It is important for the maintenance of centralized feudal rule. The emperor, as the ruler of the highest power, is independent of the supervision system. Monitoring organs for the interests of the emperor's rule are full of a strong color of "Rule by man". Supervisory organs are not independent of the emperor, but isolated from other organs. As the eyes and ears of the emperor, the independence of the supervision system was external, and its dependence on the imperial power was its essence, which made the supervision system unable to achieve its original purpose. However, these constraints, in the context of ancient historical conditions, could not be changed. This traditional system did not shed with the changes in society. The ancient supervision system was treated with the method of giving up and taking away from it. Therefore, with the continuous reform of the supervision system, we must 
adapt it to the trend of the times and accumulate effective experience for the contemporary supervision system. For example, the independence of the supervisory organs, the strict selection system of supervisors, and the importance of legal protection of the supervision system encourage the system to play its proper role in contemporary China.

\section{ACKNOWLEDGMENTS}

Project supported by the Shandong Social Science Planning Fund Program (Grant No. 18CZXZ01).

\section{REFERENCES}

[1] Liang Run. An analysis of the ancient supervision system in China [J]. Journal of Science and Education, 2019, (14):155-157.

[2] Zhao Xinyu. On the characteristics and limitations of the ancient supervision system in China[J]. Legal System and Society, 2018, (34): 233.

[3] Zhang M., Liu X.. Reflections on the supervision system in ancient China [J]. Journal of the Party School of the Shanxi Provincial Committee of the Communist Party of China, 2012,(35):89-92.

[4] Chen Yeyan. A study of ancient Chinese supervision system [D]. Baoding: Hebei University, 2016:23-25.

[5] Li Wenyue. Modern inspiration of China's ancient supervision system [D]. Nanjing: Nanjing University of Aeronautics and Astronautics, 2011: 15 .

[6] Zhang Yunxiao. Some problems in the implementation of the Supervision Law and suggestions for improvement [J]. Journal of Law, 2020,(1):48-49 .

[7] Liu Ang. Research on the legality of evidence in the implementation of the Supervision Law [J]. Evidence Science, 2018,(4):415-416 .

[8] Zhang Yunxiao. Some problems in the implementation of the Supervision Law and suggestions for improvement [J]. Journal of Law, 2020,(1):41 .

[9] Ma Jun. Exploration of the path of the rule of law of supervisory lien $[\mathrm{J}]$. Journal of Chongqing Institute of Science and Technology, 2020,(1): 18-19 .

[10] Li Chao. Ancient supervision system in China and its historical reference $[\mathrm{J}]$. Into Social Science, 2019,(1): 128 .

[11] Teng Di. The evolution of China's ancient supervision system and its inspiration for the present [J]. Science Consulting, 2018,(27):41.
[12] Zhang Guoan. On the ancient Chinese supervision system and its modern reference [J]. Law Review, 2009, (2): 149-153. 